\title{
CONFLICTS OF INTEREST AND THE CASE OF AUDITOR INDEPENDENCE: MORAL SEDUCTION AND STRATEGIC ISSUE CYCLING
}

\author{
DON A. MOORE \\ Carnegie Mellon University \\ PHILIP E. TETLOCK \\ University of California, Berkeley \\ LLOYD TANLU \\ MAX H. BAZERMAN \\ Harvard University
}

\begin{abstract}
A series of financial scandals revealed a key weakness in the American business model: the failure of the U.S. auditing system to deliver true independence. We offer a two-tiered analysis of what went wrong. At the more micro tier, we advance moral seduction theory, explaining why professionals are often unaware of how morally compromised they have become by conflicts of interest. At the more macro tier, we offer issue-cycle theory, explaining why conflicts of interest of the sort that compromise major accounting firms are so pervasive.
\end{abstract}

People rely extensively on the advice of experts. Often, these experts face conflicts of interest between their own self-interest and their professional obligation to provide good advice. Conflicts of interest played a central role in the corporate scandals that shook America at the turn of the twenty-first century. Many companies have joined Enron and WorldCom in issuing earnings restatements as a result of inaccuracies in published financial reports. Adelphia, Bristol-Myers Squibb, FastTrack Savings \& Loan, Rocky Mountain Electric, Mirant, Global Crossing, Halliburton, Qwest, AOL Time Warner, Tyco, and Xerox are some of the firms that have come under scrutiny for potentially corrupt management and a clear lack of independent financial monitoring. At the root of both this mismanagement and the failure of monitoring systems lie conflicts of interest. For example, stock options give upper management incentives to boost short-term stock prices at the expense of a company's long-term viability. And auditors charged with independently reviewing a firm's financial reports have often been found

This article has benefited from the feedback of Art Brief, George Loewenstein, and three anonymous reviewers. It was supported by a grant from the American Accounting Association. to be complicit with firm management in this effort (Levitt \& Dwyer, 2002). Accounting firms have incentives to avoid providing negative audit opinions to the managers who hire them and pay their auditing fees.

At large investment banks, research departments have become intertwined with sales departments; stock analysts seeking new business have recommended the stocks of current or potential clients to others. Happy clients boost the investment bank's business, but members of the public who heed the analysts' recommendations may not be served as well. The public receives lots of "strong buy" recommendations from analysts, a trend that increases short-term stock value at the expense of long-term investment safety (Cowen, Groysberg, \& Healy, 2003). According to Laura Unger (2001), member of the Securities and Exchange Commission (SEC), in the year 2000, a period during which the stock market was in broad decline (the Dow Jones Industrial Average dropped 6 percent, the Standard \& Poor's 500 index dropped 10 percent, and the NASDAQ dropped 41 percent), 99 percent of brokerage analysts' recommendations to their clients remained "strong buy," "buy," or "hold."

Physicians are charged with looking out for the best interest of their patients, a goal compromised by the common practice of giving re- 
ferrals to clinics and pharmacies in which they have ownership. In addition, biomedical and pharmaceutical manufacturers court physicians with free product samples, free meals, and free travel, in an attempt to influence which drugs they prescribe. Doctors are typically loath to admit that such conflicts of interest affect their judgment. Yet their very livelihood depend on another conflict of interest: prescribing services that they themselves will perform. We argue both that doctors' advice is biased by these conflicts of interest and that they typically believe their biased advice is unbiased.

Politicions elected to represent the interests of their constituents have been accused of being swayed by private interests, such as personal ties, soft money donations to political campaigns, and other factors. Special interest groups preselect and even fund "independent" research to be made public at political gatherings and public conferences. Lobbyists seeking favorable legislation bend politicians' ears, and corporations fill their campaign coffers. ${ }^{1}$

One could take the optimistic position that these conflicts of interest in the American corporate, medical, and political realm are for the most part innocuous, or that they often work to the clients' benefit. After all, those most likely to have vested interests are also those most likely to possess the most relevant expertise in a given field (Stark, 2005). For example, many both inside and outside the accounting industry have argued that an auditing firm is better equipped to handle a client's complex accounting tasks when the auditor also has deep consulting ties to that client. Similarly, a stock analyst might argue, "I would not recommend buying a stock that I myself did not own," and proponents of stock options might assert that giving managers stock options in their company ensures that these employees are financially tied to the fate of their firms. In addition, some experts believe that conflicts of interest are innocuous because,

\footnotetext{
${ }^{1}$ Of course, conflicts of interest are not unique to the United States. The success of the U.S. free market system, particularly in the late 1990s, inspired many nations to follow its policy lead. Leuz, Nanda, and Wysocki (2003) report that misleading accounting practices, such as "earnings management," are at least as common abroad as they are in the United States. Across the globe, different practices make conflicts of interest and their disclosure a particularly thorny issue for multinational corporations.
}

on the whole, professionals who face them (in medicine, law, real estate, accounting, and so on) maintain high ethical standards. According to this argument, aside from the occasional "bad apple," we can expect the great majority of doctors, politicians, CEOs, accountants, and $\mathrm{Su}-$ preme Court Justices to successfully navigate their conflicts of interest in an honest, unbiased, and noncorrupt way. However, both recent events and recent research have given us reason to question these assumptions.

Our own position can be stated simply. On the one hand, we recognize that conflicts of interest are pervasive features of life within all complex societies and that it would be prohibitively costly to try to reduce such conflicts to zero. On the other hand, we do not adopt a laissez-faire stance toward conflicts of interest. We believe that many conflicts of interest ore for from innocuous and, indeed, that abundant evidence shows that many of them have become truly egregious.

We offer two principal arguments, each of which presents a set of novel and testable theoretical propositions. The first argument is that the internal dynamics of "moral seduction" within professions encourage complacency among practitioners, as illustrated by the common assertion, "We aren't doing anything wrong." We focus on the accounting industry and offer a detailed analysis of the cognitive, organizational, and political forces that have so severely eroded auditor independence. Although it is tempting to be cynical about motivation and to assume that professionals always realize when they are succumbing to conflicts of interest, we suggest this judgment is too horsh. Putting the most Machiavellian fringes of professional communities aside, we suggest that the majority of professionals are unaware of the gradual accumulation of pressures on them to slant their conclusions- $-\alpha$ process we characterize as moral seduction. Most professionals feel that their professional decisions are justified and that concerns about conflicts of interest are overblown by ignorant or demagogic outsiders who malign them unfairly. Given what we now know generally about motivated reasoning and self-serving biases in human cognition (Kunda, 1990), and specifically about the incentive and accountability matrix within which auditors work (Bazerman, Morgan, \& Loewenstein, 1997), 
we should view personal testimonials of auditor independence with skepticism.

Our second argument has a more macro theoretical agenda: we seek to understand why society permits so many conflicts of interest to persist, despite their corrosive effects on professional advice, decision making, and the allocation of societal resources. Specifically, we argue that the external dynamics of issue cycles in the political world can deflect many regulatory and legal demands for accountability that could check conflicts of interest before they spiral out of control. We argue that organization theory could benefit from an infusion of insights from the political science literature on interest group lobbying (supplemented by insights from the psychological literature on biases and errors in judgment and decision making). Organization theorists, we believe, have placed too much emphasis on how organizations adapt to the diverse accountability demands impinging on them from the external environment (e.g., regulators, customers, courts, shareholders, and the media).

A more balanced assessment would recognize that many organizations can be politically proactive as well as reactive-norm creators as well as norm followers. We therefore propose a political psychological framework, "issue-cycle theory," that describes a cycle through which political issues move: (l) many organizations aggressively and successfully promote legislative and regulatory changes that work to their advantage; (2) these changes are often made politically palatable by public justifications that do not draw attention to the rent-seeking interests of their beneficiaries, and thus avoid drawing the attention of potentially countervailing interest groups; (3) some of these organizations overreach in their efforts and end up inflicting tangible losses (not just opportunity costs) on well-defined, influential constituencies, thus becoming the targets of political backlash; and (4) organizations often recover after outrage fades and reconcentrate their efforts at political influence.

Before presenting our two core arguments in detail, we develop our case by examining the role and history of auditing in the United States. We then build our two primary arguments regarding moral seduction and issue cycling. Together, our arguments suggest a pessimistic prognosis for would-be reformers. However, the situation is not hopeless. We conclude on an optimistic note, offering remedial recommendations specific to auditing and building on this case to offer advice on the broader topic of conflict of interest.

\section{THE ROLE AND HISTORY OF AUDITING IN THE UNITED STATES}

\section{The Role of Auditing}

The efficiency of capital markets depends on the availability of reliable information about the condition of the firms whose stock is publicly traded. Therefore, U.S. law requires that all publicly traded firms submit to audits of their financial reports, performed by independent outside auditors hired at the firm's expense. Independence requires that these audits be carried out without bias. Auditors are charged with either confirming that their clients' public financial reports have been prepared in accordance with generally accepted accounting principles (GAAP) or issuing an opinion stating otherwise. According to the American Institute of Certified Public Accountants (AICPA) Council, "Independence, both historically and philosophically, is the foundation of the public accounting profession and upon its maintenance depends the profession's strength and its stature" (Carey, 1970: 182). Simply stated, auditors are required to be independent from and unbiased by their clients' interests. As former Chief Justice Warren Burger wrote on behalf of a unanimous U.S. Supreme Court:

By certifying the public reports that collectively depict a corporation's financial status, the independent auditor assumes a public responsibility transcending any employment relationship with the client. The independent public accountant performing this special function owes ultimate allegiance to the corporation's creditors and stockholders, as well as to the investing public. This "public watchdog" function demands that the accountant maintain total independence from the client at all times and requires complete fidelity to the public trust (Burger, 1984). ${ }^{2}$

Despite this tradition, auditor independence has remained an elusive promise in the United States. While public officials and academics de-

\footnotetext{
${ }^{2}$ See Arens, Elder, and Beasley (2003) for a discussion of the legal issues involved in applying this definition to cases involving charges of audit fraud.
} 
voted some attention to failures of auditor independence prior to Enron's bonkruptcy, the public's trust in financial institutions was shaken only after the fall of Enron and its auditor, Arthur Andersen. Andersen's audit of Enron may have been the most notable failure of auditor independence, but it was by no means the first, the largest, or the last. The earnings restatement that precipitated Enron's fall revised the company's profits downward by $\$ 650$ million. Yet prior to the Enron scandal, Waste Management overstated earnings by $\$ 1.43$ billion over a five-year period, and U.S. regulators found that the company's auditor, Arthur Andersen, conspired to hide accurate accounting data from the public. Since Enron's fall, WorldCom, another Andersen client, revised its profit reports downward by a shocking $\$ 9$ billion.

Cases of audit fraud were not limited to Arthur Andersen. PricewaterhouseCoopers was forced to settle charges of fraud in connection with its audit of Tyco, a firm that has suffered a long string of accounting scandals. These cases are only the most vivid of the multitude of cases in which the major auditing firms ${ }^{3}$ paid to settle lawsuits or lost cases in the courts, partially as a result of failures of auditor independence (Bazerman, Loewenstein, \& Moore, 2002; Bazerman et al., 1997).

There is no shortage of speculation about the root cause of the many well-publicized accounting scandals. Some theories attribute them to changes in institutional arrangements, such as the increased use of stock options to compensate top managers, which created new incentives for showing ever-growing company earnings. Others point to a shift in corporate ethics, from a focus on what is morally right to a focus on what is technically legal (Moore \& Loewenstein, 2004). While corporate managers may have attempted to manipulate earnings or reports to make them look as good as possible, the consequences would have been minor had these companies' books been subjected to the kind of careful independent scrutiny the U.S. auditing system is supposed to provide.

Outside auditors are hired to provide on independent, external opinion that can certify the

\footnotetext{
${ }^{3}$ The "Final Four" major remaining accounting firms are KPMG, Deloitte \& Touche, PricewaterhouseCoopers, and Ernst \& Young.
}

truthfulness of a firm's own financial reports. Independence is the only justification for the existence of accounting firms that provide outside audits; if it were not for the claim of independence, there would be no reason for outside auditors to exist, since their function would be redundant with that of a firm's inside auditors. The assurance of independence is crucial to all of those who rely on audited financial statements for reliable information regarding a firm's financial health, including investors, lenders, employees, and strategic partners. Although a corporation's managers often have powerful incentives to make their performance appear better than it is by improving reported earnings, outside auditors are supposed to help immunize the company's financial reports from the threats posed by such incentives. Shareholders count on auditors to provide these independent reviews. Yet, for true independence to exist, auditors' reports must not be affected by any goal other than accuracy.

\section{A Brief History of Audit Regulation}

Prior to the stock market crash of 1929, there was relatively little regulation of the securities markets in the United States. The crash and the depression that followed caused public confidence in financial markets to falter. To restore faith in capital markets, Congress passed the Securities Act of 1933 and the Securities Exchange Act of 1934. These laws established what we now recognize as the SEC, required publicly traded firms to file financial reports with the SEC, and required that these reports be reviewed by independent outside auditors. Despite the SEC's mandate to set accounting standards, it has generally relied on the accounting industry to set such standards.

Over the decades, the definition of auditor independence has evolved along with the accounting profession itself. In the 1920s and 1930s the concept of independence was considered of great importance, and the focus was on eliminating conflicts of interest that arose from financial relationships between auditors and their clients. Over the following decades, the appearance of auditor independence became more important. Indeed, many in the accounting community argue that the primary value of hiring independent auditors is to reassure current and potential investors regarding a company's fi- 
nancial well-being (Antle, 1984; Dopuch, King, \& Schwartz, 2004). As early as 1932, the AICPA Council noted the need to ensure that the appearance of objectivity exists, apart from actual independence in fact (POB Panel on Audit Effectiveness Reports and Recommendations, 2002). More recently, the SEC released an appearancebased standard governing auditor independence, stating that "an auditor is not independent if a reasonable investor, with knowledge of all relevant facts and circumstances, would conclude that the auditor is not capable of exercising objective and impartial judgment" (SEC, 2000).

Given this history, it may not be surprising that the profession's response to many accounting- and audit-related crises has focused on cosmetic changes that improve the appearance of independence. Independence in appearance but not in fact has tended to increase the so-called expectations gap between (1) the expectation that companies with upbeat financial reports and "clean" audit opinions are free of the risk of short-term business failure and (2) the reality of sudden collapse among firms whose reports make them look healthy. Fogarty, Heian, and Owen (1991), Baker (1993), and Lee (1995) have noted that the U.S. accounting profession in the 1980s responded by setting up new committees to review the problem and by intensifying peer review. ${ }^{5}$ However, solutions that could have improved independence in fact, such as the setting of more tangible standards, the threat of disciplinary action, and the devel-

\footnotetext{
${ }^{4}$ An auditor's opinion can be classified into one of four types: (1) a standard unqualified opinion (in other words, a "clean" opinion that states that the auditor agrees the financial statements are presented fairly-which refers to a lack of misinformation-and in accordance with GAAP); (2) an unqualified opinion with an explanatory paragraph or modified wording (which means that the audit was satisfactory but that the auditor believes the firm should provide additional information); (3) a qualified opinion (in which the auditor states that the financial statements are fairly presented, but the scope of the audit was materially limited or statements were not prepared in compliance with GAAP); and (4) an adverse opinion (in which the auditor is unable to form an opinion as to whether the financial statements are fairly presented) or a disclaimer (which means that the auditor is not independent; Arens, Gordon, Narayanamoorthy, \& Zhou, 2003).

${ }^{5}$ The recent requirement that major accounting firms submit to quality audits by the Public Companies Accounting Oversight Board is consistent with this approach.
}

opment of new audit procedures, were not pursued (Fogarty et al., 1991; Reiter \& Williams, 2000).

In June 2000 the SEC drafted a strong proposal designed to improve auditor independence in fact. The SEC proposal explicitly spelled out limitations on financial and personal relationships between the employees of auditing firms and their audit clients, and it enumerated a list of banned nonaudit services, including financial system design and implementation and internal audit outsourcing. The major accounting firms lobbied hard against the proposed limitations on their consulting work and dramatically increased their political contributions to the major political parties (Mayer, 2002). Shortly thereafter, members of Congress pressured the SEC and its chairman, Arthur Levitt, to implement much weaker reforms than those initially sought (Levitt \& Dwyer, 2002). The resulting compromise allowed auditors to continue offering consulting services but required firms to disclose how much they paid their auditors for both audit and nonaudit services.

This new rule did not prevent the financial scandals at Enron and WorldCom, which created enough public outrage that Congress passed the Sarbanes-Oxley Act of 2002. The act introduces several reforms, such as the formalization of the accountability of the CEO and CFO for the company's financial statements, increased civil and criminal sanctions against directors or managers accused of fraud, and more stringent and comprehensive disclosure and internal control requirements. ${ }^{6}$ Companies are required to ensure that their audit committees are staffed with independent (external) directors and have at least have one financial expert.

In addition, the act has attempted to address auditor issues in two broad ways. First, it has federalized regulation and governance of auditing firms through the creation of the Public Company Accounting Oversight Board (PCAOB),

\footnotetext{
${ }^{6}$ Among the more controversial features of the act is Section 404, which requires managers and auditors to provide personal assurance as to the effectiveness of internal controls over financial reporting. Corporations are expected to spend approximately $\$ 5.8$ billion in 2005 (Kawamoto, 2004) in order to successfully comply with Section 404. It is unclear, however, how the expected benefits (i.e., increased credibility, or at least the appearance thereof) compare with these massive costs.
} 
the purpose of which is to establish and promulgate audit standards to which accounting firms must abide, as well as to inspect, investigate, and, whenever appropriate, sanction public accounting firms for failure to comply with these standards. Second, the act includes a number of stipulations designed to increase auditor independence, but these changes concern appearance more than fact. For example, many have endorsed the act's stipulation that auditors rotate assignments every five years. Yet the act in fact only requires the rotation of the lead audit partner, not the audit firm itself. Press reports also have highlighted the act's ban on the provision of nonaudit services but typically ignored two facts: (1) the ban omits important services, such as tax services, and (2) Provision 201b of the act allows the new PCAOB to "exempt any person, issuer, public accounting firm, or transaction from the prohibitions on the provision of services..." on a case-by-case basis.

Furthermore, while the act prohibits employees of audited firms from being hired by their auditors, this prohibition applies only to those who have served as CEO, CFO, controller, or chief accounting officer at the client firm, and it only limits them from auditing their former employers for one year. The act does nothing to limit the hiring of auditors by client firms, which is for more common than the reverse. In other words, while the act appears to address importont issues surrounding auditor independence, it is insufficient to create true auditor independence. In legislation, the proverbial devil lurks in the details-details that special interests can often successfully influence as long as politicians project the image of decisive action to the broader public.

\section{THE MORAL SEDUCTION OF THE ACCOUNTING PROFESSION}

The United States, like many nations, has institutionalized a set of regulations governing auditing that create on environment in which auditor independence is virtually impossible. While financial markets would benefit from a reduction in the conflicts of interest that permeate auditors' work, there are a number of obstacles to such changes. First, we discuss structural features of the auditor-client relationship that create conflicts of interest. Second, we detail the cognitive processes by which these structures exert their effects on auditors' professional judgment.

\section{Structural Features of the Auditing Profession}

The current auditing system institutionalizes at least three potential threats to independence: managers hiring and firing auditors, auditors taking positions with clients, and auditors providing nonaudit services.

Managers hiring and firing auditors. Clients, who have the freedom to choose their auditors, have many reasons to select an auditing firm based on the likelihood the auditor will deliver an affirmative audit opinion. The fact that the probability a client will switch auditors increases following a critical audit report is likely to reduce the auditor's desire to file such a report (Levinthal \& Fichman, 1988; Seabright, Levinthal, \& Fichman, 1992). One practice that auditors might use to signal their willingness to accommodate the client's wishes is known as "low-balling": offering a discounted price for audit services in order to build a relationship that could become profitable later, either by increasing audit fees or by cross-selling services. There is some evidence that low-balling increases auditors' willingness to acquiesce to the client's desires (Beeler \& Hunton, 2003, but see also DeAngelo, 198la, and Lee \& Gu, 1998).

Some researchers have posited that the size of the audit firm will affect the degree to which the firm fears being fired by its client. DeAngelo (1981a) and Simunic (1984) argue that larger audit firms ought to be more resistant to client pressure to manipulate reported earnings, and Eichenseher (1984) and Palmrose (1986) suggest that "brand-name" auditors are at least perceived to be more independent. However, research in this area has been inconclusive. Pany and Reckers (1980) and McKinley, Pany, and Reckers (1985) failed to find on effect of audit firm size. Even if the audit firm itself does not depend on any specific client for its survival, the careers of particular audit partners depend a great deal on their success with individual accounts. Overall, however, we only have indirect evidence of whether hiring and firing decisions negatively influence audit quality (for a more thorough review of this literature, see Nelson, 2005).

Auditors taking jobs with clients. Auditors' independence from their clients is compromised 
by any relationship that builds a common identity between the two. Psychological research on the "minimal group paradigm" has demonstrated how easy it is to establish a group identity that leads people to favor fellow ingroup members (Tajfel \& Turner, 1986). Thompson (1995) has shown that even the most superficial affiliation with a partisan leads people to interpret ambiguous information in ways that are consistent with the partisan's interests. Indeed, several studies have found that auditor independence and the quality of auditing decisions deteriorate over time as the auditor-client relationship lengthens (Beck, Frecka, \& Solomon, 1988; Dies \& Giroux, 1992; Mautz \& Sharaf, 1961).

In addition, there can hardly be a more effective means of establishing a common identity between auditor and client than rotating personnel between the two. This was the case in Andersen's relationship with Enron, as it is with other accounting firms and their clients. Obviously, independence is compromised when on auditor hopes to develop job opportunities with the audited firm. The minimal restrictions on personnel rotation established by the SarbanesOxley Act are clearly insufficient, given the high frequency with which auditors at all levels take jobs with audit clients.

Auditors providing nonaudit services. Much of the debate surrounding auditor independence has focused on the provision of nonaudit services by audit firms to their audit clients. In 1978 the SEC required companies to disclose any nonaudit services their auditors performed for them if and when the fees paid to the auditor for nonaudit services were at least 3 percent of the audit fees paid. However, this requirement was repealed in 1982. The SEC concluded that the required disclosure "was not generally of sufficient utility to investors to justify continuation" (SEC, 1982), despite evidence showing that knowledge of a consulting relationship creates a perceived lack of auditor independence (Former, Rittenberg, \& Trompeter, 1987; Gul, 1991; Knapp, 1985; Pany \& Reckers, 1983; Shockley, 1981; Turpen, 1995).

Nonaudit services proved to be an important growth area for accounting firms. By 1999, fees for nonaudit services had grown to 66 percent of revenues and 70 percent of profits for the major accounting firms (POB Panel on Audit Effectiveness Reports and Recommendations, 2002). Some evidence has suggested that high consult- ing fees have indeed biased auditors' judgment (Frankel, Johnson, \& Nelson, 2002; Kinney, Palmrose, \& Scholz, 2004; Ruddock, Sherwood, \& Taylor, 2004). However, these conclusions are controversial (Antle et al., 2002; Ashbaugh, LaFond, \& Mayhew, 2003; Butler, Leone, \& Willenborg, 2002; Chung \& Kallapur, 2003; Craswel, Stokes, \& Laughton, 2002; Larcker \& Richardson, 2004).

\section{How Conflicts of Interest Affect Judgment}

Perhaps the most notable feature of the psychological processes at work in conflicts of interest is that they can occur without any conscious intention to indulge in corruption. This fact can also help explain why citizens accept policies that allow conflicts of interest to persist. The field of accounting-and public policy in the United States more broadly-has been dominated by an economic lens of analysis (Ferraro, Pfeffer, \& Sutton, 2005). Consistent with this economic approach, in models of auditor independence, researchers have assumed that independence is a question of whether the auditor chooses to carry out a thorough, unbiased audit or collude with a firm's managers (Antle, 1984; DeAngelo, 1981b; Simunic, 1984). Psychological research on the impact of motivated reasoning and self-serving biases questions the validity of this assumption. This evidence suggests that intentional corruption is probably the exception, and that unconscious bias is far more pervasive. This distinction between conscious corruption and unconscious bias is important, because the two respond to different incentives and operate in different ways.

Selective perception. Evidence on unconscious bias suggests that people are not very good at disregarding their own self-interest and evaluating information impartially, even when they try to do so. When choosing how to allocate scarce resources, people honestly believe that they deserve more than independent observers think they deserve (Messick \& Sentis, 1979). People justify self-serving decisions by using the arguments that happen to favor them (Diekmann, 1997; Diekmann, Samuels, Ross, \& Bazerman, 1997; Messick \& Sentis, 1983), without awareness of this selectivity. Ignorance of these self-serving biases can have important consequences for economic decisions (Babcock \& Loewenstein, 1997; Thompson \& Loewenstein, 1992). 
People appear to evaluate evidence in a selective fashion when they have a stake in reaching a particular conclusion. They focus on evidence that supports the conclusion they would like to reach (Holyoak \& Simon, 1999; Koehler, 1991; Lord, Ross, \& Lepper, 1979; Russo, Medvec, \& Meloy, 1996; Russo, Meloy, \& Medvec, 1998; see Rabin \& Schrag, 1999, for a theoretical model). When they cannot ignore conflicting evidence, they often subject it to additional critical scrutiny (Gilovich, 1991). This tendency toward biased information processing prevails even when people on different sides of an issue are exposed to the same information (Babcock, Loewenstein, Issacharoff, \& Camerer, 1995).

While some observers have suggested that professional auditors might be less affected by these biases, research has shown that professionals are vulnerable to the same motivated biases as laypeople (Buchman, Tetlock, \& Reed, 1996; Cuccia, Hackenbrack, \& Nelson, 1995). Once auditors learn and encode information from a partisan perspective, they are no longer able to objectively assess the data, and they view ambiguous data consistent with the preference of their clients (Babcock et al., 1995; Messick \& Sentis, 1979; Thompson \& Loewenstein, 1992).

Plausible deniability. When it comes to biased judgments, evidence suggests that people are more willing to endorse a biased proposal made by someone else than to make one on their own. Diekmann et al. (1997) have shown that people tend to be somewhat more cautious about indulging their biased preferences when they are asked to make their own independent proposals than when they are asked only to approve or reject a proposal made by someone else. The current system, in which auditors are charged only with assessing whether or not the client's reports comply with GAAP, is likely to exploit the tendency to "go along" with the actions of another, even when those actions raise some questions or concerns.

Escalation of commitment. Another important bias specifically relevant to the realm of conflict of interest is the tendency of people to escalate their commitment to a previous course of action (Brockner \& Rubin, 1985; Staw, 1976). One question that has repeatedly been asked since the collapse of Enron is how Arthur Andersen ever signed off on Enron's accounting procedures. Our hypothesis is that, at least in part, moral seduction occurs one step at a time. For example, in one year, an auditor might decline to demand that the client change an accounting practice that is at the edge of permissibility. The next year, the auditor may feel the need to justify the previous year's decision and may turn a blind eye when the client pushes just past the edge of permissibility. The following year, the auditor might endorse accounting that clearly violates GAAP in order to avoid admitting the errors of the past two years, in the hope that the client will fix the problem before the next year's audit. By the fourth year, the auditor and client will both be actively engaged in a cover-up to hide their past practices. One regulatory reform that would reduce escalation of commitment would be a requirement that companies rotate auditor firms on a specified time schedule.

More broadly, we imagine that many behaviors in the realm of conflicts of interest begin as minor questionable calls that sometimes escalate into violations of ethical standards and the law. We expect that escalation in the acceptance of unethical behavior will be especially pronounced to the degree that acting ethically would require one to disappoint those with whom one works every day and to accept immediate punishment (loss of income and social status, and perhaps legal penalties). In contrast, the unethical path would require one to live with a difficult-to-gauge probability of eventual disclosure and humiliation some time in the indefinite future. Faced with the choice between a guaranteed loss of income and status on the one hand and the chance of a more severe penalty (and the chance that one might never be punished) on the other, people tend to opt for the risky option (Kahneman \& Tversky, 1979, 2000; Schweitzer, Ordonez, \& Duouma, 2004).

Many have argued that accounting firms have a real interest in reporting a breach of accounting if it exists, given the real threats of legal penalties and shareholder lawsuits. This interest should lead accounting firms to establish systems that could counteract the threats to independence posed by the issues described above. While it is clearly true that accounting firms do have an interest in preserving their reputations and avoiding legal charges of fraud, it is entirely unclear whether these distant and probabilistic threats are sufficient to counteract real and immediate incentives to build relationships with clients and sell them services, espe- 
cially given reductions in the threat of legal penalties. ${ }^{7}$ Furthermore, even if accounting firms have an interest in creating unbiased reports, individual auditors, whose careers may depend on building relationships with their clients, and who may even be interested in working for those clients, face very different incentives.

Incccuracies in self-perception. Conflict of interest increases as financial incentives and professional obligations clash. The greater the incentives created for professionals to act against their obligations to society or to their clients, the greater the expected deviation from professionally defined normative behavior will be. These incentives are likely to lead professionals both to increase their defense of the ethical rectitude of their profession and to resist changes that could actually resolve the conflict of interest.

Conflicts of interest hinder people from making objective assessments, yet professionals often deny that their decisions are biased by conflicts of interest. In medicine, ample evidence documents the biasing influence of gifts from and sponsorship by pharmaceutical companies (Bower \& Burkett, 1987; Caudill, Johnson, Rich, \& McKinney, 1996; Dana \& Loewenstein, 2003; Wazana, 2000), yet physicians strenuously deny that their clinical judgment is compromised by such blandishments (Hume, 1990). Accountants also deny corruption. In his testimony before the SEC, Gary Shamis, then chairman of the Management of an Accounting Practice Committee of the AICPA, stated, "We take the existing independence rules quite seriously, and consequently abide by all the existing rules. We are professionals that follow our code of ethics and practice by the highest moral standards. We would never be influenced by our own personal financial well being" (Shamis, 2000). Although such sentiments are noble, they do not constitute strong evidence for actual objectivity.

Effects of accountability. The literature on accountability predicts that the types of accountability pressures operating on professionals in conflict-of-interest situations should exacerbate rather than attenuate the motivated reasoning

\footnotetext{
${ }^{7}$ The Securities Reform Act of 1995, passed with generous support from the accounting industry, changed the standard for assessing liabilities in securities fraud cases from joint and several to proportionate liability, thereby significantly reducing the liabilities faced by accounting firms.
}

underlying moral seduction. The principal accountability pressure at work is justifying one's professional practices to powerful, opinionated audiences with well-defined views-namely, one's clients and one's superiors. In a predecisional setting these accountability demands encourage strategic attitude shifting, which need not be conscious (Cialdini, Petty, \& Cacioppo, 1981), and the selective generation of reasons to justify going along with dominant-audience expectations (Tetlock, 1983, 1992). In a postdecisional setting these types of accountability demands encourage postdecisional bolstering and the selective generation of reasons to justify what one has already done (Staw, 1976; Tetlock \& Lerner, 1999).

The literature on debiasing judgment strongly suggests that there is no silver-bullet accountability solution for ensuring that auditing professionals do not engage in the types of motivated reasoning underlying moral seduction. Ironically, the accountability literature suggests that the best solution to the corrupting effects of conflicts of interest may well be to create countervailing interests that compel practitioners to become painfully self-conscious and preemptively self-critical about their auditing practices. Defenders of the status quo might argue that the courts already serve this role. But this type of formal legal accountability is highly uncertain, activated only in the most egregious cases, generally has been for removed in time, and is far less salient than immediate accountability pressures from clients who prefer self-serving solutions to auditing problems and from partners within the accounting firm who prefer to maximize billable hours.

To be effective, accountability for the implementation of high professional standards must come much more rapidly and much more directly from within the firm-as, in principle, existed within Arthur Andersen through its internal watchdogs in the Professional Standards Group, whose job it was to hold Andersen auditors to the highest standards of accuracy and independence. However, the recommendations of the Professional Standards Group regarding the Enron account were overruled at the highest levels of the firm (McRoberts, 2002). There is a critical need for regulatory and legal protection of internal professional standards groups that enforce the types of accountability shown in the laboratory literature to encourage complex and 
self-critical forms of reasoning-for example, accountability to audiences whose expertise is esteemed, whose respect is needed, and whose own views cannot be easily inferred (Tetlock \& Lerner, 1999).

The search for a smoking gun. Too many reform efforts have fallen victim to the human tendency to focus on simple causes of complex problems (McGill, 1989). In their 2000 hearings, SEC commissioners searched for the proverbial "smoking gun" that would prove bias on the part of identifiable auditor culprits. The commissioners were looking for an email or memo that would provide clear evidence of knowing and intentional corruption. Lobbyists for the accounting industry and CEOs from Big Five accounting firms noted that there was no evidence of a single audit being tainted as a result of the auditing-consulting relationship.

Although such evidence may sometimes emerge (as it did in the Waste Management case), proving that a particular case of audit fraud was caused by the presence of nonaudit services is nearly as difficult as proving that any particular smoker's lung cancer is due to smoking; each case is complicated by numerous confounding factors. More important, this standard of proof falsely assumes that the most common threat to auditor independence is intentionally corrupt behavior. If the real threat is unconscious bias, auditors may never make a smoking gun statement that reveals corrupt intent, because no corrupt intent exists. We need to change the system, not simply lock up the guilty parties.

Recent legislative changes also address the problem by attempting to pin the blame more closely on specific individuals. The SarbanesOxley Act makes a firm's chief executive and chief financial officers personally liable for inaccuracies in financial reports, yet it does little to reform the deeper problems with the institutional structure of auditing.

The institutionalization of a search within the legal system for corrupt actors is broadly consistent with the psychological tendency to attribute behavior to individual dispositions, talents, or failings, rather than to situational constraints or opportunities (Jones \& Harris, 1967; Ross \& Nisbett, 1991). This judgmental error leads people to attribute the cause of an event or problem to an individual, as opposed to the broader situation or context (see Morris \& Moore,
2000). Thus, even when institutional arrangements create conflicts of interest, we too often seek a corrupt person to punish, rather than examine the flaws in the system or fight against those who lobby to keep the broken system in place. Therefore, legislative barriers to resolving conflicts of interest are partly rooted in cognitive barriers.

From the standpoint of moral seduction theory, one does not need to be Machiavellian or sociopathic to succumb to conflicts of interest. Indeed, psychological evidence suggests that the overwhelming majority of human beings, placed in such circumstances, would respond in roughly the same fashion. Although many observers are surprised and depressed that so few whistle-blowers protest moral lapses in their organizations, the psychological literature tells us to appreciate the fact that any individuals come forward to blow the whistle at all.

\section{WHY ARE CONFLICTS OF INTEREST SO PERVASIVE?}

Through its minimal oversight of the auditing profession, the U.S. legislative system allowed conflicts of interest to become pervasive in the industry. The history of the accounting profession in the twentieth and now early twenty-first centuries fits a cyclical pattern in political issues that has been well documented by political scientists who study the lobbying efforts of special interest groups (such as accountants, CEOs, medical doctors) seeking regulatory and legal advantages for their members. Just as one person's freedom fighter is another's terrorist, so, too, one observer's venal special interest is another's legitimate professional association exercising its voice in a democracy (Tetlock \& Mitchell, 1993). The advantages secured by specific interest groups can occasionally become so flagrant that they attract the attention of the broader public. The resulting scandals trigger countervailing political influence and widespread condemnation of the excesses of private action, causing at least temporary setbacks for the special interests. Once the outrage wanes, the special interests once again take the political offensive, poking low-visibility loopholes in the high-visibility legislation (e.g., SarbanesOxley Act) that politicians point to as evidence of their responsiveness to the public's concerns. 
This issue-cycle analysis draws on two key strands of political theory: stasis theory and countervailing power theory. Interest group stasis theory posits on inevitable trend in which well-connected interests gain control over government policies on a piecemeal basis, each group controlling policies in its own area of activity. Over time, this produces the political economic equivalent of arteriosclerosis (sometimes called "demosclerosis"; Rauch, 1995). Stasis theory posits the trend to be inevitable because it is individually rational. It is rational because it would not benefit any individual to incur the time and money costs of organizing the larger society around widely shared interests, such as the desire for true auditor independence or $a$ loophole-free tax system. As a result, these shared interests will receive less direct support in the political process (Lowi, 1964, 1969; Olson, 1965, 1982). Symbolic political commitments can overcome this powerful inertial lag for only brief periods of time, usually through bouts of outrage. Smaller concentrated groups thus have on inherent advantage over larger diffuse ones for the simple reason they are less subject to the free rider problem (Brewer \& Kramer, 1986; Kerr, 1989; Pruitt, 1998; Yamagishi, 1992).

Some stasis theorists also add that very diffuse and unorganized publics are particularly prone to irrational perceptions of political reality (Rauch, 1995). Such publics confuse symbol with substance, making it easy to manipulate mass opinion by creating political forms that give the impression that a problem is being solved or a policy is being pursued when this is not the case. For example, many observers have noted the political advantages that have accrued from the confusion over the "Healthy Forests Initiative" (the Healthy Forests Restoration Act of 2003), a law opening up significant new areas to logging and deforestation by private interests. While 70 percent of the American public identifies itself as environmentalist (per a National Environmental Survey conducted for the Competitive Enterprise Institute in 1998), this large and inchoate group is less likely to appreciate the niceties of forest regulation than are the logging companies themselves. Political groups consisting of a well-defined sector of business do not usually confuse symbol with substance. Such small groups, following organized political strategies, will frequently prevail over the interests of large publics confused by political symbols and strategies. The combination of intelligence and money is hard to beat.

Of course, stasis theory explains only the build-up-to-scandal phase of the issue cycle. Countervailing power theorists, such as Wilson (1980) and Walker (1983), have noted that the pattern of interest group organization is often complex, with many groups effectively organized to influence policy in particular arenas. The complex pattern of group organization means that other groups often exercise countervailing power to the special interest group that might otherwise dominate an area of policy (Becker, 1983). Building on this work, and on behavioral economic theories of fairness that posit the willingness of observers to incur additional losses to punish cheaters (Fehr \& Gächter, 2000), we hypothesize that countervailing power is most likely to be mobilized when coolitions of adversely affected group members perceive that particular concentrated interests have gone too far, "pigging out" and inflicting real losses (beyond opportunity costs) on the members of the larger society.

While clearly in tension with each other, stasis and countervailing power theories are not mutually exclusive. It is perfectly possible that interest group stasis is a widespread background condition of political and economic life but that concentrated interest groups often overreach, producing the backlash effects described by countervailing power theorists. This dynamic goes a long way toward explaining the ambivalence of the American public toward interest group politics. Most Americans recognize that interest group actions (especially those of their own interest groups, which they tend to identify as professional associations or community action) are indispensable for the functioning of $a$ modern democracy. But they also distrust interest groups (especially those of others), fearing that groups will abuse their legitimate power (Schlozman, 1984).

To our issue-cycle approach we add that the success of interest groups in pursuing their private ends without activating countervailing power is a function of both how careful they are to avoid pushing their agenda too aggressively and how skillfully they mask rent seeking in the rhetoric of the public good. Accountants did not declare that they wanted to be free to make as much money as possible by offering as wide a range of profitable services as possible. Rather, 
they cloaked their claims in the ideology of the free market and economic efficiency, as in a now-famous letter from Kenneth Lay, then chairman of Enron, to Arthur Levitt, then chairman of the SEC, explaining why Andersen should be allowed to continue offering both auditing and consulting services to Enron. This letter, which was authored not by Lay but by Andersen's lead audit partner at Enron, David Duncan, claimed that Andersen's expanded role was "valuable to the investing public, particularly given the risks and complexities of Enron's business and the extremely dynamic business environment in which Enron and others now operate" (Lay, 2000).

The willingness of outsiders-potential sources of countervailing power-to give credence to the rhetorical posturing of one's interest group will decline in relation to the magnitude of the perceived losses one's interest group is inflicting on outsiders. Kenneth Lay's letter once packed considerable political clout; today, it is a painful reminder of past excesses. Thus, issue-cycle theory suggests a definition of prudent long-term political advocacy for interest groups: good advocates know where they are in the issue cycle. These advocates capitalize on opportunities to push hard for regulatory advantoges in benign environments where they can fly below the radar screens of potential adversaries. Good advocates also know when it will be difficult to hide under rhetorical smokescreens and when to back off before triggering scandal and backlash.

Finally, when thinking about the dynamics of issue cycles, it is critical to consider the political psychological nature of the most common target of special interest influence: our legislative system. Legislators are not philosopher kings who seek ideal solutions to problems such as auditor independence or sugar price supports (Wildavsky, 1988). Rather, they typically ask what adjustments, if any, should be made to the status quo (Baron, 1996; Bazerman, Baron, \& Shonk, 2001), making the existing system an anchor for future policy (Samuelson \& Zeckhauser, 1988). Solving conflicts of interest requires significant changes to government policy.

When it comes to changing the status quo, Baron (1988) argues that humans have an irrational preference for harms of omission over harms of action. When contemplating a change in policy, many people (legislators) follow the rule of thumb, "Do no harm." Thus, legislators are more likely to be concerned with the harms that they create through action (legislative change) than those they create through inaction. This tendency to harm through omission rather than commission leads parties to maintain the status quo, even when change would improve cumulative societal welfare.

The status quo and omission biases make us reluctant to eliminate important conflicts of interest when their elimination would impose small costs on specific, and likely vocal, members of society. Those with a vested interest in the status quo (such as the major accounting firms and investment banks) are typically more willing to invest resources to maintain the status quo than the forces for reform can expend on inducing change. Overwhelming evidence is often necessary to build up the necessary political momentum to change legislation (Tetlock \& Boettger, 1994). Rather than ask what the best system would look like, legislators ask whether public pressure warrants changes to the status quo. As legislators might say in their defense, politics is the art of the possible.

A second set of issues arises when we consider why we, as a society, fail to adequately address destructive conflicts of interest. In a sense, the failure of auditor independence is rooted in the failure to resolve politicians' conflicts of interest between representing the voters and funding their political campaigns. In the presidential primaries of the 2000 election, campaign finance reform finally caught the attention of the public when both Bill Bradley and John McCain made it an issue. Public outrage was fanned by publicity about wasteful and harmful subsidies, such as the U.S. government's \$83.5 million annual assistance to tobacco growers (Bazerman et al., 2001). How do special interest group politics and the failure of meaningful campaign finance reform play out in the U.S. auditing system?

When SEC Chairman Arthur Levitt considered significant reforms to the auditing system, he became the target of what he later called an "intensive and venal lobbying campaign" (Labaton, 2002). The accounting industry convinced forty-six members of Congress to call or write letters to Levitt questioning the proposed reforms (Center for Responsive Politics, 2002). Most of the lawmakers argued that accounting firms should be trusted. Some threatened to withdraw 
funding from the SEC and to conduct ethics reviews of the commissioners. Especially vociferous in their defense of the accounting industry were Representative Billy Tauzin, who went on to oversee the House Energy and Commerce Committee's investigation into Enron, and Representative Dick Armey, the House majority leader.

In total, these forty-six members received millions of dollars in campaign contributions from the Big Five accounting firms (Center for Responsive Politics, 2002). The major accounting firms and the AICPA, their trade association, contributed more than $\$ 38$ million to the political process between 1989 and 2001 (see Table 1). In the face of this political pressure, Levitt backed down from his tough stance, although he later called his decision to back down the biggest mistake of his SEC tenure (Mayer, 2002). The Sarbanes-Oxley Act ultimately passed after public outrage created by the fall of Enron and other firms, accomplishing some of Levitt's goals. While the current law introduces some important reforms, they are clearly insufficient, focusing on intentional corruption and overlooking the conflicts of interest built into the system.

While we do not deny that corrupt auditors exist, we argue that a focus on corruption neglects what is probably a far more important source of violations of auditor independence: unconscious, and hence unintentional, bias. This brings us to the point of reconciling the two tiers of our theory. At the macro level, we have depicted organizations as aggressively and strategically exploitative. Yet our microlevel explanation for the behavior of individuals suggests far less avaricious intent; indeed, our review of the individual-level psychological evidence suggests that people strive to view themselves as fair and even-handed. We do not believe that these two views are, in fact, contradictory. It is precisely because individuals are so good at serving their own self-interests while persuading themselves that their actions are perfectly reasonable that firms and individuals can provide sensible explanations for their exploitative behavior. The most effective lies are those we believe ourselves. Furthermore, even if most people are constrained from exploiting others for individual gain, the competitive forces at work on organizations favor those groups that effectively seek their own gain, even if this means establishing routines and practices that circumvent or modify the more fair-minded motives of most of the organization's members.

\section{FUTURE RESEARCH OPPORTUNITIES}

The explanations we have offered in this paper point to a number of testable propositions. Here, we mention five topics that offer opportunities for future study. First, the theory of issue cycling outlined in this article implies that special interest groups will be more effective at achieving the interests of their members when their motives for seeking special advantage for their members are effectively veiled behind explanations that invoke more virtuous motives. Indeed, the direct and declared attempt to pursue one's self-interest at the expense of society as a whole will be rare, because such naked power grabs are both unseemly and ineffective. Political lobbying will be less unseemly and more persuasive to the degree it can be plausibly justified in terms of the broader social good. And attempts at political influence will be less likely to be effective when their uncamouflaged announcement activates countervailing political pressure. Of course, there are plausibility constraints and the attitude change literature suggests that, especially in a repeated-play game, interest groups are well advised not to make morally self-aggrandizing claims that shade into the audience's latitude of rejection (Petty \& Wegener, 1998). Persuasion is a delicate art.

Second, our theory of moral seduction proposes that ethical lapses are more likely to occur gradually, as the result of the process of escalation, than they are to occur rapidly. Given that ethical standards often create gray areas of ambiguous ethical propriety, people will find themselves crossing into the zone of ethical violation after they have first committed actions that are ambiguous in their appropriateness. We predict that it will be relatively rare for people's behavior to lapse suddenly into ethical violation, because such a jump is more difficult to justify or rationalize to oneself.

Third, we have argued that moral seduction is facilitated by automatic (unconscious) psychological processes. Because few people think of themselves as intentionally corrupt, our theory predicts that corruption more likely will occur when the cognitive processes can operate unconsciously and the individual can preserve a 
TABLE 1

Lobbying Expenditures of Accounting Firms During Calendar Years 1997-2003

\begin{tabular}{llrrrr}
\hline Year & Arthur Andersen & $\begin{array}{l}\text { Deloitte \& } \\
\text { Touche }\end{array}$ & Ernst \& Young & KPMG & $\begin{array}{r}\text { Pricewaterhouse } \\
\text { Coopers }\end{array}$ \\
\hline 1997 & $\$ 2,380,000$ & $\$ 785,000$ & $\$ 1,380,000$ & $\$ 600,000$ & $\$ 900,000$ \\
1998 & $1,985,000$ & 360,000 & $1,420,000$ & 420,000 & 960,000 \\
1999 & $1,840,000$ & 890,000 & $1,200,000$ & 850,000 & $1,220,000$ \\
2000 & $2,480,000$ & $2,524,000$ & $1,200,000$ & $1,340,000$ & $1,425,000$ \\
2001 & $1,540,000$ & 580,000 & $1,320,000$ & $1,175,000$ & $1,240,000$ \\
2002 & - & $1,027,455$ & $2,343,860$ & $1,430,000$ & $3,160,000$ \\
2003 & - & 660,000 & $1,980,000$ & 925,000 & $1,680,000$ \\
\hline
\end{tabular}

Source: Data from the Office of Public Records (http://sopr.senate.gov).

${ }^{\alpha}$ The 1997 total is a combined total of Price Waterhouse and Coopers \& Lybrand, which were then separate companies.

view of himself or herself as moral. We have also claimed that the distinction between conscious and unconscious processing is important, because conscious corruption and unconscious bias respond to different incentives. Exactly how corruption and bias respond to incentives is a topic that deserves future study. When are bias and corruption likely to act in concert, and when are they likely to move independently? Under what circumstances do biases become conscious, and under what circumstances does corruption become so automatic that it becomes unconscious?

Fourth, our perspective raises important questions regarding the view of individuals and of organizations. The two are at odds in the picture painted by our theory. If people genuinely prefer to behave morally and fairly, even when it is costly for them to do so (Fehr, Kirchler, Weichbold, \& Gaecher, 1998; Loewenstein, Thompson, \& Bazerman, 1989), how is it that organizations so often behave in devious and exploitative ways? How do organizations circumvent or co-opt their members' preferences? What organizational practices or routines facilitate this co-optation? One possibility is that many organizations tacitly adopt a personality-based division of labor, in which personnel with hardball Machiavellian world views do disproportionate shares of ethically compromising corporate work: wooing large, ethically suspect clients and funneling campaign money and other implicit quid pro quos to key political actors (for a review of the extensive literature on Machiavellianism, see Wilson, Neor, \& Miller, 1996).

Fifth, our theory raises some questions about the political processes by which business activity is regulated. Our economic system assumes that corporations will pursue the goal of maximizing the wealth of their owners within the bounds of the law (Corr, 1968; Friedman, 1953). $\mathrm{We}$, the people, elect legislators who create the laws that regulate the run of business interests and create the legal boundaries within which businesses must operate. The problems we highlight in this article arise from a situation in which corporations wield political influence over the laws that govern their own actions. The reason why issue-cycle theory matters for businesses is that it can help us understand how business interests obtain political advantage. Free market systems have tremendous virtues, such as the way in which competition and selfinterest spur the efficient allocation of wealth. However, our approach questions whether it is appropriate for corporations to exercise undue influence over the rules under which they operate. The question of corporations' rightful role in the political process - of what constitutes undue influence-is a complex topic that we do not resolve, but we do note that there is, once again, plenty of ambiguity on which motivated reasoning can operate in specific controversies.

\section{RESOLVING CONFLICTS OF INTEREST}

Given the cognitive and political barriers to solving the problems created by conflicts of interest, it is unlikely that society will ever entirely eliminate them. Nevertheless, that does not mean that it is impossible to limit their worst excesses. Here, we explore possible avenues for creating auditor independence. Congress, President George W. Bush, and the SEC have all put forth or passed measures aimed at making auditors more independent. But these policy 
changes have focused on increasing penalties for corruption and punishing corrupt individuals. While important first steps, research suggests that they are based on an incorrect understanding of the main source of auditor bias and, therefore, are inadequate solutions to a systemic problem. Mild reforms and the occasional legal penalty will not provide true auditor independence, and more corporations will fail as a result.

One popular response to the problems associated with conflicts of interest has been disclosure (Former et al., 1987; Independence Standards Board, 2000; Shafer, Morris, \& Ketchand, 1999; Shockley, 1982). But recent research suggests that disclosure cannot be assumed to protect consumers of biased information. Indeed, disclosure can sometimes make matters worse; professionals may be more willing to give biased advice when they know that the person receiving the advice is aware of their conflict of interest (Cain, Loewenstein, \& Moore, 2005). Also, recipients of biased advice are likely to have difficulty using disclosures effectively. Evidence has shown that people are easily influenced by advice, even when they know that it has been designed to manipulate them and they consciously attempt to resist its influence (Comerer, Loewenstein, \& Weber, 1989; Strack \& Mussweiler, 1997).

We believe there are two possible means of fixing the U.S. auditing system. The first solution would leave the existing auditor-client relationship largely intact but increase its regulation in five key ways. First, we believe that auditors should perform audits and no other services. Second, we believe that an audit firm should be hired for a fixed period, perhaps five years. During this period, to reduce the auditor's incentive to please the client with a positive opinion, the client must not be able to fire the auditor. Following this fixed period, the auditor assignment should rotate, not to another partner within the same firm (as is the case under the Sarbanes-Oxley Act), but to a different accounting firm. ${ }^{8}$ Third, all parties

\footnotetext{
${ }^{8}$ Our proposal of forced audit firm rotation is not new. It was considered as a means of increasing auditor independence at least as early as the 1976 Metcalf Report (U.S. Senate, 1976; as cited in Zeff, 2003) and as recently as 2003 (U.S. General Accounting Office, 2003). Opponents of mandatory auditor rotation have noted the costs of implementing
}

involved in the audit-executives and staff alike-should be prohibited from taking jobs with the firms they audit. Fourth, auditors should make a set of independent assessments, rather than simply ratify the accounting of the client firm. Fifth, the auditor should be chosen not by company management but by the audit committee of the board of directors. The hiring decision concerning who should make an independent assessment of a firm's finances should not reside with those whose work will be evaluated.

These five steps would add a great deal of governmental regulation to the auditor-client relationship. Enforcing these laws would likely be costly to government. For those who do not like such heavy-handed regulation, another solution can be created based on market principles. Ronen (2002) has proposed eliminating the legal requirement that publicly traded firms submit to regular audits of their financial reports. Instead, firms would be required to buy financial statement insurance to insure against the possibility of being sued for issuing inaccurate financial reports. In this system the sellers of such insurance-the insurance companies-would hire the auditors, and the insurance premiums they charged would be a signal of their confidence in the accuracy of public reports.

Neither of these solutions is costless or easy. But we have a real problem, and the accounting industry has done its best to deny the problem. We believe that the costs created by either of these proposals makes sense compared to the current system, which offers false claims of independence and false assurance to the users of corporate financial statements.

We view these recommendations as a blueprint for thinking about how to solve conflict of interest problems in a general sense. To cure conflicts of interest, we need to study them,

such a change, as well as the potential erosion of audit quality that may theoretically result. We believe, however, that this risk is overstated, for the following two reasons. First, a cozy, long-term relationship between auditor and client is as great a risk to audit quality as is auditor unfamiliarity with the client. Second, auditors' concern for their reputations will, if anything, increase, since they will need to find future clients once they are required to leave their current clients. Note, however, that empirical research is mixed as to whether mandatory rotation actually enhances or harms audit quality (Arel, Brody, \& Pany, 2005; Dopuch, King, \& Schwartz, 2001; George, 2004). 
identify the structural changes needed to eliminate them, and think strategically about how to overcome the cognitive and political barriers to structural reforms. Conflict of interest is easily understood, yet mobilizing action to correct deeply rooted problems is difficult. Similarly, auditor independence is an easy concept to grasp, yet it is difficult to implement. In this article we have attempted to show that a corrupting system has been institutionalized across levels in one domain of conflict of interest-from the mind of the auditor to the structures that govern the industry, and from legislation to the political process that creates it. Investors, shareholders, and financial markets depend on independently audited corporate financial reports, yet the system has never provided true independence. Only through a radical reorganization of the industry will the term auditor independence accurately describe auditors' work in the United States. Many may argue that such dramatic reforms may be costly. Yet doing nothing yields even greater risks; indeed, we may not be able to afford not to make these changes.

Clearly, there are multiple causes for the failure of auditor independence. The basic ground rules of our political system have prevented necessary legislative reform, this faulty legislative system has institutionalized a corrupt set of structures, and these structures have led to biased decisions and occasionally outright corruption. Current laws have created an inefficient, unethical, and wasteful system. Stiglitz (1998) argues that wise government should strive to create near-Pareto efficient changes. With 280 million citizens in the United States, it is difficult to create changes that have no losers. However, in some cases there exist parties that have an unfair advantage owing to their distortion of the political process. We believe that this is the case in the auditing system and that the costs of creating true independence are worthwhile for the government, the financial markets, and for the vast majority of citizens. As is generally the case in problems of conflict of interest, only those audit firm partners and co-opted executives who have benefited from the corrupt system would lose in the creation of true auditor independence. In the case of the U.S. auditing system, basic structural reform will be profoundly difficult to achieve, yet essential.

\section{REFERENCES}

Antle, R. 1984. Auditor independence. Journal of Accounting Research, 22: 1-20.

Antle, R., Gordon, E. A., Narayanamoorthy, G., \& Zhou, L. 2002. The joint determination of audit fees, non-audit fees, and abnormal accruals. Working paper, Yale University, New Haven, CT.

Arel, B., Brody, R. G., \& Pany, K. 2005. Audit firm rotation and audit quality. CPA Journal, 75: 36-39.

Arens, A. A., Elder, R. J., \& Beasley, M. S. 2003. Auditing and assurance services (9th ed.). Upper Saddle River, NJ: Prentice-Hall.

Ashbaugh, H., LaFond, R., \& Mayhew, B. 2003. Do non-audit services compromise auditor independence? Further evidence. Accounting Review, 78: 611-639.

Babcock, L., \& Loewenstein, G. 1997. Explaining bargaining impasse: The role of self-serving biases. Journal of Economic Perspectives, 11: 109-126.

Babcock, L., \& Loewenstein, G., Issacharoff, S., \& Camerer, C. F. 1995. Biased judgments of fairness in bargaining. American Economic Review, 85: 1337-1343.

Baker, C. R. 1993. Self-regulation in the public accounting profession: The structural response of the large public accounting firms to a changing environment. Accounting, Auditing, \& Accountability Journal, 6: 99-108.

Baron, J. 1996. Do no harm. In D. M. Messick \& A. E. Tenbrunsel (Eds.), Codes of conduct: 197-213. New York: Russell Sage Foundation.

Baron, J. 1998. Judgment misguided: Intuition and error in public decision making. New York: Oxford University Press.

Bazerman, M. H., Baron, J., \& Shonk, K. 2001. You can't enlarge the pie: The psychology of ineffective government. New York: Basic Books.

Bazerman, M. H., Loewenstein, G., \& Moore, D. A. 2002. Why good accountants do bad audits. Harvard Business Review, 80(1): 87-102.

Bazerman, M. H., Morgan, K. P., \& Loewenstein, G. F. 1997. The impossibility of auditor independence. Sloan Management Review, 38(4): 89-94.

Beck, P., Frecka, T., \& Solomon, I. 1988. An empirical analysis of the relationship between MAS involvement and auditor tenure: Implications for auditor independence. Journal of Accounting Literature, 7: 65-84.

Becker, G. S. 1983. A theory of competition among pressure groups for political influence. Quarterly Journal of Economics, 98: 371-400.

Beeler, J. D., \& Hunton, J. E. 2003. Contingent economic rents: Insidious threats to auditor independence. Working paper, Millsaps College, Jackson, MS.

Brockner, J., \& Rubin, J. Z. 1985. The social psychology of entrapment in escalating conflicts. New York: SpringerVerlag.

Bower, A., \& Burkett, G. 1987. Family physicians and generic drugs: A study of recognition, information sources, pre- 
scribing attitudes, and practices. Journal of Family Practice, 24: 612-616.

Brewer, M. B., \& Kramer, R. M. 1986. Choice behavior in social dilemmas: Effects of social identity, group size, and decision framing. Journal of Personality and Social Psychology, 50: 543-549.

Buchman, T. A., Tetlock, P. E., \& Reed, R. O. 1996. Accountability and auditors' judgment about contingent events. Journal of Business Finance and Accounting, 23: 379-398.

Burger, W. 1984. United States v. Arthur Young \& Co., Vol. 82-687, Supreme Court of the United States.

Butler, M. B., Leone, A. J., \& Willenborg, M. 2002. An empirical analysis of auditor reporting and its association with abnormal accruals. Working paper, University of Rochester, Rochester, New York.

Cain, D. M., Loewenstein, G., \& Moore, D. A. 2005. The dirt on coming clean: Perverse effects of disclosing conflicts of interest. Journal of Legal Studies, 34: 1-25.

Camerer, C. F., Loewenstein, G., \& Weber, M. 1989. The curse of knowledge in economic settings: An experimental analysis. Journal of Political Economy, 97: 1232-1254.

Carey, J. L. 1970. The rise of the accounting profession: To responsibility and authority, 1937-1969. New York: American Institute of Certified Public Accountants.

Carr, A. Z. 1968. Is business bluffing ethical? Harvard Business Review, 46(1): 143-153.

Caudill, T., Johnson, M., Rich, E., \& McKinney, P. 1996. Physicians, pharmaceutical sales representatives, and the cost of prescribing. Archives of Family Medicine, 5: 201206.

Center for Responsive Politics. 2002. http://www.opensecrets. org. Washington, DC: Center for Responsive Politics.

Chung, H., \& Kallapur, S. 2003. Client importance, non-audit fees, and abnormal accruals. Accounting Review, 78: 931-955.

Cialdini, R. B., Petty, R. E., \& Cacioppo, J. T. 1981. Attitude and attitude change. Annual Review of Psychology, 32: 357404.

Cowen, A., Groysberg, B., \& Healy, P. 2003. Which types of analyst firms make more optimistic forecasts? Harvard Business School NOM Working paper No. 03-46. http:// ssrn.com/abstract $=436686$.

Craswell, A., Stokes, D. J., \& Laughton, J. 2002. Auditor independence and fee dependence. Journal of Accounting and Economics, 33: 253-275.

Cuccia, A. D., Hackenbrack, K., \& Nelson, M. W. 1995. The ability of professional standards to mitigate aggressive reporting. Accounting Review, 70: 227-248.

Dana, J., \& Loewenstein, G. 2003. A social science perspective on gifts to physicians from industry. Journal of the American Medical Association, 290: 252-255.

DeAngelo, L. E. 198la. Auditor independence, low balling, and disclosure regulation. Journal of Accounting and Economics, 3: 113-127.

DeAngelo, L. E. 1981b. Auditor size and audit quality. Journal of Accounting and Economics, 3: 183-199.
Diekmann, K. A. 1997. "Implicit justifications" and selfserving group allocations. Journal of Organizational Behavior, 18: 3-16.

Diekmann, K. A., Samuels, S. M., Ross, L., \& Bazerman, M. H. 1997. Self-interest and fairness in problems of resource allocation: Allocators versus recipients. Journal of Personality and Social Psychology, 72: 1061-1074.

Dies, D., \& Giroux, G. 1992. Determinants of audit quality in the public sector. Accounting Review, 67: 462-479.

Dopuch, N., King, R. R., \& Schwartz, R. 2001. An experimental investigation of retention and rotation requirements. Journal of Accounting Research, 39: 93-117.

Dopuch, N., King, R. R., \& Schwartz, R. 2004. Contingent rents and auditors' independence: Appearance vs. fact. Asia Pacific Journal of Accounting and Economics, June: 4568.

Eichenseher, J. 1984. The effects of foreign operations on domestic auditor selection. Journal of Accounting, Auditing, and Finance, 8: 195-209.

Farmer, T. A., Rittenberg, L. E., \& Trompeter, G. M. 1987. An investigation of the impact of economic and organizational factors on auditor independence. Auditing: $A$ Journal of Practice and Theory, 7: 1-14.

Fehr, E., \& Göchter, S. 2000. Cooperation and punishment in public goods experiments. American Economic Review, 90: 980-994.

Fehr, E., Kirchler, E., Weichbold, A., \& Gaecher, S. 1998. When social norms overpower competition: Gift exchange in experimental labor markets. Journal of Labor Economics, 16: 324-351.

Ferraro, F., Pfeffer, J., \& Sutton, R. I. 2005. Economics language and assumptions: How theories can become selffulfilling. Academy of Management Review, 30: 8-24.

Fogarty, T. J., Heian, J. B., \& Owen, D. 1991. The rationality of doing "nothing": Auditors' responses to legal liability in an instutionalized environment. Critical Perspectives on Accounting, 2: 201-226.

Frankel, R. M., Johnson, M. F., \& Nelson, K. K. 2002. The relation between auditors' fees for non-audit services and earnings management. Accounting Review, 77: 71105.

Friedman, M. 1953. Essays in positive economics. Chicago: University of Chicago Press.

George, N. 2004. Auditor rotation and the quality of audits. CPA Journal, 74: 22-27.

Gilovich, T. 1991. How we know what isn't so: The fallibility of human reason in everyday life. New York: Free Press.

Gul, F. 1991. Size of audit fees and perceptions of auditors' ability to resist management pressure in audit conflict situations. Abacus, 27: 162-172.

Holyoak, K. J., \& Simon, D. 1999. Bidirectional reasoning in decision making by constraint satisfaction. Journal of Experimental Psychology: General, 128: 3-31.

Hume, A. L. 1990. Doctors, drug companies, and gifts [letter]. Journal of the American Medical Association, 263: 16931697. 
Independence Standards Board (ISB). 2000. Statement of independence concepts: $A$ conceptual framework for auditor independence. Exposure draft ED 00-2. http:// www.nasba.org/NASBAfiles.nsf/Lookup/ED002/\$file/ ED002.pdf, accessed March 2005.

Jones, E. E., \& Harris, V. A. 1967. The attribution of attitudes. Journal of Experimental Social Psychology, 3: 1-24.

Kahneman, D., \& Tversky, A. 1979. Prospect theory: An analysis of decision under risk. Econometrica, 47: 263-29l.

Kahneman, D., \& Tversky, A. (Eds.). 2000. Choices, values, and frames. New York: Russell Sage Foundation.

Kawamoto, D. 2004. New piece of Sarbanes-Oxley kicks in. CNET News.com. http://news.com.com/New + piece + of + Sarabanes-Oxley+kicks +in/2100-7355_3-5453279.html, accessed March 2005.

Kerr, N. L. 1989. Illusions of efficacy. The effect of group size on perceived efficacy in social dilemmas. Journal of Experimental Social Psychology, 25: 287-313.

Kinney, W. R., Palmrose, Z., \& Scholz, S. 2004. Auditor independence, non-audit services, and restatements: Was the U. S. government right? Journal of Accounting Research, 42: 561-588.

Knopp, M. 1985. Audit conflict. An empirical study of the perceived ability of auditors to resist management pressure. Accounting Review, 60: 202-211.

Koehler, D. J. 1991. Explanation, imagination, and confidence in judgment. Psychological Bulletin, 110: 499-519.

Kunda, Z. 1990. The case for motivated reasoning. Psychological Bulletin, 108: 480-498.

Labaton, S. 2002. Enron's collapse. The lobbying: Audit firms exercise power in Washington. New York Times, January 19: 1.

Larcker, D., \& Richardson, S. 2004. Fees paid to audit firms, accrual choices, and corporate governance. Journal of Accounting Research, 42: 625-658.

Lay, K. 2000. Letter to Arthur Levitt. http://www.pbs.org/wgbh/ pages/frontline/shows/regulation/congress/lay.html, accessed July 2004.

Lee, C., \& Gu, Z. 1998. Low balling, legal liability and auditor independence. Accounting Review, 73: 533-555.

Lee, T. 1995. The professionalization of accountancy. Accounting, Auditing, \& Accountability Journal, 8(4): 48-70.

Leuz, C., Nanda, D., \& Wysocki, P. D. 2003. Earnings management and investor protection: An international comparison. Journal of Financial Economics, 69: 505-527.

Levinthal, D. A., \& Fichman, M. 1988. Dynamics of interorganizational attachments: Auditor-client relationships. Administrative Science Quarterly, 33: 345-369.

Levitt, A., \& Dwyer, P. 2002. Take on the street: What Wall Street and corporate America don't want you to know, and what you can do to fight back. New York: Pantheon.

Loewenstein, G., Thompson, L., \& Bazerman, M. H. 1989. Social utility and decision making in interpersonal contexts. Journal of Personality and Social Psychology, 57: 426-441.

Lord, C. G., Ross, L., \& Lepper, M. R. 1979. Biased assimilation and attitude polarization. Journal of Personality and Social Psychology, 37: 2098-2109.

Lowi, T. J. 1964. American business, public policy, case studies and political theory. World Politics, 16: 677-715.

Lowi, T. J. 1969. The end of liberalism. New York: Norton.

Mautz, R., \& Sharaf, H. 196l. The philosophy of auditing. Sarasota, FL: American Accounting Association.

Mayer, J. 2002. The accountants' war. New Yorker, April 22: 64-72.

McGill, A. L. 1989. Context effects in judgments of causation. Journal of Personality and Social Psychology, 57: 189200.

McKinley, S., Pany, K., \& Reckers, P. 1985. An examination of the influence of CPA firm type, size, and MAS provision on loan officer decisions and perceptions. Journal of Accounting Research, 23: 887-896.

McRoberts, F. 2002. The fall of Andersen. Chicago Tribune, September 1: Al.

Messick, D. M., \& Sentis, K. P. 1979. Fairness and preference. Journal of Experimental Social Psychology, 15: 418-434.

Messick, D. M., \& Sentis, K. P. 1983. Fairness, preference, and fairness biases. In D. M. Messick \& K. S. Cook (Eds.), Equity theory: Psychological and sociological perspectives: 61-94. New York: Praeger.

Moore, D. A., \& Loewenstein, G. 2004. Self-interest, automaticity, and the psychology of conflict of interest. Social Justice Research, 17: 189-202.

Morris, M. W., \& Moore, P. C. 2000. The lessons we (don't) learn: Counterfactual thinking and organizational accountability after a close call. Administrative Science Quarterly, 45: 737-765.

Nelson, M. W. 2005. A review of experimental and archival conflicts-of-interest research in auditing. In D. A. Moore, D. M. Cain, G. Loewenstein, \& M. H. Bazerman (Eds.), Conflicts of interest: Challenges and solutions in law, medicine, and organizational settings: 41-69. Cambridge: Cambridge University Press.

Olson, M. 1965. The logic of collective action. Cambridge, MA: Harvard University Press.

Olson, M. 1982. The rise and decline of nations. New Haven, CT: Yale University Press.

Palmrose, Z. 1986. Audit fees and auditor size. Journal of Accounting Research, 24: 97-110.

Pany, K., \& Reckers, P. 1980. The effect of gifts, discounts, and client size on perceived auditor independence. Accounting Review, 55: 50-61.

Pany, K., \& Reckers, P. 1983. Auditor independence and nonaudit services: Director views and their policy implications. Journal of Accounting and Public Policy, 2: 43-62.

Petty, R., \& Wegener, D. 1998. Attitude change: Multiple roles for persuasion variables. In D. Gilbert, S. Fiske, \& G. Lindzey (Eds.), Handbook of social psychology, vol. 1: 323-390. New York: McGraw-Hill.

POB Panel on Audit Effectiveness Reports and Recommendations. 2002. http://www.pobauditpanel.org/download.html, accessed August 2003. 
Pruitt, D. G. (Ed.). 1998. Social conflict (4th ed.). New York: McGraw-Hill.

Rabin, M., \& Schrag, J. L. 1999. First impressions matter: A model of confirmatory bias. Quarterly Journal of Economics, 114: 37-82.

Rauch, J. 1995. Demosclerosis: The silent killer of American government. New York: Random House.

Reiter, S. A., \& Williams, P. F. 2000. The history and rhetoric of auditor independence concepts. http://les.man.ac.uk/ ipa/papers/44.pdf, accessed March 2005.

Ronen, J. 2002. Post-Enron reform: Financial statement insurance, and GAAP revisited. Stanford Journal of Law, Business, and Finance, 8(1): 1-30.

Ross, L., \& Nisbett, R. E. 1991. The person and the situation: Perspectives of social psychology. New York: McGrawHill.

Ruddock, C., Sherwood, K., \& Taylor, S. 2004. Non-audit services and earnings management: Is auditor independence impaired? Working paper, University of New South Wales, Sydney, Australia.

Russo, E. J., Medvec, V. H., \& Meloy, M. G. 1996. The distortion of information during decisions. Organizational Behavior and Human Decision Processes, 66: 102-110.

Russo, J. E., Meloy, M. G., \& Medvec, V. H. 1998. Predecisional distortion of product information. Journal of Marketing Research, 35: 438-452.

Samuelson, W., \& Zeckhauser, R. 1988. Status quo bias in decision making. Journal of Risk and Uncertainty, 1: 7-59.

Schlozman, K. 1984. What accent the heavenly chorus? Political equality and the American pressure system. Journal of Politics, 46: 1006-1032.

Schweitzer, M. E., Ordonez, L., \& Duouma, B. 2004. Goal setting as a motivator of unethical behavior. Academy of Management Journal, 47: 422-432.

Seabright, M. A., Levinthal, D. A., \& Fichman, M. 1992. Role of individual attachments in the dissolution of interorganizational relationships. Academy of Management Journal, 35: 122-160.

Securities and Exchange Commission (SEC). 1982. Relationships between registrants and independent accountants. Accounting Series Release (ASR) No. 304. Washington, DC: SEC

Securities and Exchange Commission (SEC). 2000. Final rule: Revision of the commission's auditor independence requirements. SEC Standard Release. Securities and Exchange Commission 17 CFR Parts 210 and 240, file No. S7-13-00 [RIN: 3235-AH91]. http://www.sec.gov/rules/final/ 33-7919.htm, accessed August 2004.

Shafer, W. E., Morris, R. E., \& Ketchand, A. A. 1999. The effects of formal sanctions on auditor independence. Auditing: A Journal of Practice and Theory, 18(Supplement): 85101.

Shamis, G. 2000. SEC hearing on auditor independence. http://www.sec.gov/rules/proposed/s71300/testimony/ shamisl.htm, accessed August 2004.
Shockley, R. A. 1981. Perceptions of auditors' independence: An empirical analysis. Accounting Review, 55: 785-800.

Shockley, R. A. 1982. Perceptions of auditor independence: A conceptual model. Journal of Accounting, Auditing, and Finance, 5: 126-143.

Simunic, D. 1984. Auditing, consulting, and auditor independence. Journal of Accounting Research, 22: 679-702.

Stark, A. 2005. Why are (some) conflicts of interest in medicine so uniquely vexing? In D. A. Moore, D. M. Cain, G. Loewenstein, \& M. H. Bazerman (Eds.), Conflicts of interest: 152-180. Cambridge: Cambridge University Press.

Staw, B. M. 1976. Knee-deep in the big muddy: A study of escalating commitment to a chosen course of action. Organizational Behavior and Human Performance, 16: 27-44.

Stiglitz, J. 1998. The private uses of public interests: Incentives and institutions. Journal of Economic Perspectives, 12: 3-22.

Strack, F., \& Mussweiler, T. 1997. Explaining the enigmatic anchoring effect: Mechanisms of selective accessibility. Journal of Personality and Social Psychology, 73: 437446.

Tajfel, H., \& Turner, J. C. 1986. The social identity theory of intergroup behavior. In S. Worchel \& W. Austin (Eds.), The psychology of intergroup relations (2nd ed.): 7-24. Chicago: Nelson-Hall.

Tetlock, P. E. 1983. Accountability and complexity of thought. Journal of Personality and Social Psychology, 45: 74-83.

Tetlock, P. E. 1992. The impact of accountability on judgment and choice: Toward a social contingency model. Advances in Experimental Social Psychology, 25: 331-376.

Tetlock, P. E., \& Boettger, R. 1994. Accountability amplifies the status quo effect when change creates victims. Journal of Behavioral Decision Making, 7: 1-23.

Tetlock, P. E., \& Lerner, J. S. 1999. The social contingency model: Identifying empirical and normative boundary conditions on the error-and-bias portrait of human nature. In S. Chaiken \& Y. Trope (Eds.), Dual-process theories in social psychology: 571-585. New York: Guilford Press.

Tetlock, P. E., \& Mitchell, P. G. 1993. Liberal and conservative approaches to justice: Conflicting psychological portraits. In B. Mellers \& J. Baron (Eds.), Psychological perspectives on justice: 234-255. Cambridge: Cambridge University Press.

Thompson, L. 1995. "They saw a negotiation": Partisanship and involvement. Journal of Personality and Social Psychology, 68: 839-853.

Thompson, L., \& Loewenstein, G. 1992. Egocentric interpretations of fairness and interpersonal conflict. Organizational Behavior and Human Decision Processes, 51: 176197.

Turpen, R. A. 1995. Audit fees: What research tells us. CPA Journal, 65: 54-56.

Unger, L. 2001. How can analysts maintain their independence? Speech given to the Ray Garrett Jr. Corporate 
and Securities Law Institute, Northwestern University School of Law, Chicago.

U.S. General Accounting Office. 2003. Public accounting firms: Required study on the potential effects of mandatory audit firm rotation (GAO-04-216). http://www. gao.gov/cgi-bin/getrpt?GAO-04-216, accessed March 2005.

U.S. Senate. 1976. The accounting establishment. Staff study prepared by the Subcommittee on Reports, Accounting, and Management of the Committee on Government Operations, United States Senate, 94th Congress, 2nd Session. Washington, DC: U.S. Government Printing Office.

Walker, J. L. 1983. The origins and maintenance of interest groups in America. American Political Science Review, 77: $390-406$.

Wazana, A. 2000. Physicians and the pharmaceutical indus- try: Is a gift ever just a gift? Journal of the American Medical Association, 283: 373-380.

Wildavsky, A. 1988. The new politics of the budgetary process. Glenview, IL: Scott, Foresman.

Wilson, D. S., Near, D., \& Miller, R. R. 1996. Machiavellianism: A synthesis of the evolutionary and psychological literatures. Psychological Bulletin, 119: 285-300.

Wilson, J. Q. (Ed.). 1980. The politics of regulation. New York: Basic Books.

Yamagishi, T. 1992. Group size and the provision of a sanctioning system in a social dilemma. In W. B. G. Liebrand, D. M. Messick, \& H. A. M. Wilke (Eds.), Social dilemmas: Theoretical issues and research findings: 267-287. Oxford: Pergamon Press.

Zeff, S. A. 2003. How the U.S. accounting profession got where it is today: Part II. Accounting Horizons, 17: 267-286.

Don A. Moore is an associate professor of organizational behavior at the Tepper School of Business at Carnegie Mellon University. He received his Ph.D. from Northwestern University. He studies human decision making, including how people compare themselves with others and how decisions can be distorted by conflicts of interest.

Philip E. Tetlock is the Lorraine Tyson Mitchell Chair in Leadership and communication professor of leadership at the Haas School of Business at the University of California, Berkeley. He received his Ph.D. from Yale University. His research examines learning from experience, accountability, and how to debias judgment and choice.

Lloyd Tanlu is a doctoral student in accounting at Harvard Business School, Harvard University. His research interests include budgeting, internal control systems, and conflicts of interest in accounting.

Max H. Bazerman is the Jesse Isidor Straus Professor of Business Administration at Harvard Business School, Harvard University. He received his Ph.D. from Carnegie Mellon University. His research interests include managerial decision making, bounded awareness, bounded ethicality, and societal decision making. 
Copyright of Academy of Management Review is the property of Academy of Management and its content may not be copied or emailed to multiple sites or posted to a listserv without the copyright holder's express written permission. However, users may print, download, or email articles for individual use. 